\title{
A STUDY OF FATAWAS (RELIGIOUS DECREES) REGARDING TEACHING AND LEARNING ENGLISH LANGUAGE
}

\author{
Muhammad Imran Saeed \\ Lecturer, Humanities Department, COMSATS University Islamabad, Vehari Campus \\ imransaeed@ciitvehari.edu.pk \\ Dr Saeed Ahmad \\ Assistant Professor, Department of English, The Islamia University of Bahawalpur, Bahawalnagar Campus \\ saeed_ahmad@iub.edu.pk \\ Muhmmad Nasir \\ Lecturer, Department of English, Institute of Southern Punjab Multan \\ legendguy143@yahoo.com
}

\begin{abstract}
The present study discusses Muslim religious scholars' attitudes in the sub-continent when it was under British rulers' influence. The study focuses on the causes of religious scholars' indifference and their hostile attitudes towards the English language in the pre-partition era. The data has been collected from various fatawa books written by Muslim religious scholars during the pre-partition period. Researchers analyse the fatawas (religious decrees) under the paradigm of Islam and English language and attitudes of religious scholars in the pre- partition era. The fatawas has been examined through a content analysis of the text. The study's findings reveal that Muslim religious scholars were against English language learning and teaching to such an extent that they issued Fatawas declaring that learning and teaching English was illegitimate (Najaiz) because they believed that Christian missionaries were against Muslims and Islam. The findings further suggest that future English language curriculum planning should consider society's cultural and religious requirements so that everyone in the community can learn English according to their needs. The study also highlights cultural harmony from the perspective of English language learning.
\end{abstract}

KEYWORDS: Fatawas, Religious Scholars, Teaching and Learning, and English Language

Article Received: 10 August 2020, Revised: 25 October 2020, Accepted: 18 November 2020

\section{BACKGROUND AND LITERATURE REVIEW:}

Europe and other western nations were awakening from a long slumber of ignorance during the Renaissance period. Navigators were discovering new routes and parts of the world. New facts were being found, and old beliefs were being disproved. New fields of knowledge were sprouting. Commerce and trade had reached their pinnacle. Traders were voyaging all over the world with more excellent prospects. Apart from business, hegemonic designs were also lying behind these voyages. Under the umbrella of their backing governments, different trading companies were strengthening their powers in other countries.

In 1600, the East India Company arrived in India with the British government's help. Because the British could not gain unchallenged power until September 1803, when General Lord Lake victoriously entered Delhi, its arrival also marked the English language's arrival into India. However, it wasnot taught to the natives for the next two hundred years. From Poona, a central city, to Calcutta, a coastal town, British rule had already been established. This strange rule impacted every aspect of the subcontinent's collective life. It had a significant effect on native life, particularly in the legal, educational, and philosophical spheres. Without a doubt, the British represented a particular culture, and the spread of their culture and languagein the subcontinent was unavoidable as their rule grew stronger.

Christian missionaries were instrumental in spreading the English language across the subcontinent. They saw it as a useful tool for spreading Christianity. During the East India Company's rule, Charles Grant (1746-1823) was a pivotal figure who worked tirelessly to civilize the Indians through English language and literature. He wanted to enforce British laws and declare English as the official language and instruction language in schools and colleges. He believed that the government should not support nonChristian religious education in Sanskrit or other languages. He was convinced that the only way to 
eliminate all social and moral evils and widespread illiteracy and ignorance was to spread modernEnglish language education (Siddique, 1965). As a result, religious scholars viewed English as a westernization tool. Modern education, they claimed, was incompatible with their beliefs, culture, society, and traditions (Ali, 2003). That was the source of the Muslim religious community's opposition. Indians, particularly Muslims, believed that after receiving an education in the English language and literature, students would become anti-religious and embrace Christianity. That was why Muslims disliked studying or learning English, and they were strongly opposed to mission schools and English language learning (Ali, 2003). When Muslims in Calcutta heard that the Indian government wanted to promote English education, they prepared a request (signed by 8000 peers and scholars) to summarize that the British government's unusual concentration on English language education declares that thegovernment wants to Christianize Indians (Ali, 2003).

The Muslims were already facing a severe economic crisis due to a lack of employment opportunities in government offices. Still, after 1835, when English was declared the courts' official language and government offices, most Persian-literate Muslims lost their jobs. Muslims were declared ineligible for all government jobs except peon and water-sprinkler because they were illiterate in the English language. It also harmed their financial situation. In these circumstances, it became unavoidable for Muslims to obtain modern education and a working knowledge of the English language if they wished to work forthe government. The scholars who came forward to confront the Christian missionaries felt compelled and motivated to learn English in that situation. Doctor Muhammad Wazir Khan helped MaulanaRehmatUllahKeranvi learn English (Ali, 1993). During his time in England, Dr. Wazir Khan learned a lot about Christianity and Judaism from English, Latin, and Hebrew books. During his stay and employment in Agra, he also brought a largelibrary of Latin-Greek, Hebrew, and English books on Christianity and Judaism. He took a stand in front of the Christian missionaries. Both scholars challenged and defeated Christian Bishop Carl Gottlieb Pounder (Thanesari, 1962). Another reason for the ulama's apathy toward English language teaching and learning was Sir Syed Ahmad khan's religious and educational interpretation. Sir Syed Ahmed Khan, who fought to improve the Muslims' situation, discovered that improving their economic and political situation was impossible without a modern education and communicating in English
(Mian, 1964). As a result, he presented English literature and modern education to Muslims with zeal. Through his journal "Tahzeeb-e-Ikhlaq" (Mian, 1964), he insisted on the importance of English education to the people. In summary, Sir Syed strongly advocated for the acquisition of modern education and the English language. In 1857, he founded Madrissa-tulAloom, and in 1878, he founded Muhammadan Anglo-Oriental College in Aligarh. He advocated for learning English and English manners and habits (Naumani, 1989). As a result, religious scholars saw English as a means of westernization. There have been reports of Muslim religious scholars despising English and modern education. The British Chief Commissioner Oadh requested to meet with renowned Muslim scholar Abdul-Razzaq Frangi Mehl, but he refused. He even refused to use British products and refused to travel by train (Naumani, 1989). Hafiz Muhammad Ismaeel, another religious scholar, did not see a single British face. He did not speak a single English word for the rest of his life. He went by the name 'Tomatar,' whichwas an Urdu translation of the word 'Tomato,' which meant 'Lalbangan' (Nidvi, 1976). However, there are some specific examples of how to learn English. During his imprisonment, Muslim religious scholar Muhammad Jafar Thanesari learned English from a Hindu, Ram Saroop. With his knowledge of English, he achieved good excellence in that language. Heaided many Muslims, saving them from the deathpenalty (Gillani, 1976). The eldest Ahle-Hadith scholar, Syed Nazir Hussain Dehlvi, was one of the first to issue a 'Fatwa' in favour of learning Englishfor the sake of employment (Dehlvi, 1960). In 1866, Dar-ulAloom Deoband was founded. Its curriculum did not include the English language or modern education. Its founders had no preference for or support for English education. They were unconcerned about it. Molvi Qasim Nanotiv, the organization's founder, was aware of the importance of the English language, but he preferred to focus solely on Islamic knowledge. He believed that English was already being taught in government schools and colleges and that further promotion was unnecessary. After completing their Islamiceducation, he advised students to seek moderneducation from government institutions (Nasir-ud- Din, 1992). Molvi Syed Nazir Hussain Dehlvi, who founded the Madrissa-eAhmadia institute in Shahabad, Behar Province, in 1890 , was the first in the subcontinent to include the English language in the Madrissa syllabus. Dar-ulAloom is a mosque in Dar-ul-Aloom, Pakistan Molvi Muhammad Ali Mongeri founded Nidwa-tul-Ulma in Lakhnu in 1898. The English language was also included in the curriculum, and a class for English as a second 
language was established in 1902. A teacher was also assigned to the task (Ali, 1993). Shibli Naumani, a renowned Nidwa scholar, wanted to include English and modern education to compete with Christian missionaries. He wanted Muslim religious scholars to learn English to advise the educated, respond to Christian preachers, and correct their misconceptions. Due to the issue's sensitivity, some Ulama, including Maulana Habib Sherwani, a well-known, moderate religious scholar, did not support Shibli (Nidvi, 2003). Finally, in 1903, English was made a compulsory subject in Madrissah's curriculum, and Shibli's efforts were not in vain. A few students from Dar-ul-Uloom provided excellent services in education and religion after learning English. In 1915, Maulana Hakeem Syed Abdul Ala was accepted into a missionary school in lakhnu and completed his matriculation. In 1919, he earned aB.Sc. in English literature and botany with honours. In 1925, he received his M.B.B.S. from King George Medical College (Ali, 1993). Molvi Abdul Bari, another religious scholar who established Madrisah- e-Nazamia at Farangi Mahal, was one of the prominent Ulamas who advocated for English teaching at Islamic institutions (Hassan, 2002). The ulama at Farangi Mahal, on the other hand, did not have much success in this regard. Even though much effort had been put in, the students were uninterested. Although students gained a basic understanding of English due to these efforts, the fruit did not reach therequired level.

During the second and third decades of the twentieth century, there was a significant change regarding the religious education among Ulama Farangi Mahal. The new generation started learning English and modern education. One of the most important aspects of this change was that the elders themselves took that decision (Hassan, 2002).

Until 1950, most of the family's young generation, including girls, had turned to learn English and modern education. Setting an example of learning English at a religious institution, on the other hand, was a bold move. The current trend in English teaching and learning is changing because learning English is simple. There are also good teachers and English language learning materials available everywhere. As a Madrassah teacher from Khyber Pakhtunkhwa sees it, English allows us to communicate Islam to others, learn about Judaismand Christianity, achieve harmony, and learn.

\section{Significance of the Study:}

It was necessary to know Muslim religious scholars' attitudes during research on the English language in the social and educational context because they are an active part of our society and education system. This research will help develop societal attitudes toward English language learning and teaching. It's also helpful in tracing the historical roots of religious scholars' perspectives. It could be beneficial for policymakers to design different syllabuses for Madrassah students based on their needs.

\section{Objectives of the Study:}

1. To learn about religious scholars' attitudes toward English language learning and teaching in the past

2. To learn about religious scholars' positiveand negative attitudes toward English language learning and teaching

3. To learn about the reasons for their aversion to the English language

\section{Methodology of the Study:}

The current study is qualitative in nature, and the researchers gathered the data by going through various fatawas books. Fourteen fatwas were chosen at random from different books by well-known religious scholars. After the data collection, Fatawas were analysed through content analysis.

\section{Analysis:}

The fourteen Fatwas used in this study were delivered by well-known religious scholars and were analysed in different dimensions:

1. Religious scholars permit the study and teaching of English, but only under certain conditions. They believe that there is no harm in learning and teaching in this dimension.

If the English language does not impact the teachers' and students' Islamic values and identities, it is acceptable. "It is permitted if a person learns English so that he will be able to understand books and hidden meanings of words," says Shah Abdul Aziz Muhadis Dehlvi in Fatwa No. 2. "It is rightto learn English until nobody is culpable of calamity as well as it will be harmful toIslam," says Maulana Rashid Ahmed Gangohi in fatwa No. 6. "Learning of language, whether the language of non- Muslims is not prohibited in Islam, this is in fact to acquire English language education is not prohibited according to sharia," says Maulana Abdul Hai in Fatwa No. 11.

2. They also permit the study and teaching of English when it is only beneficial to 
Muslims and Islam. They believe it should combat prejudice against Muslims, Islam, and modern philosophy. "Learning of English language is compulsory to oppose modern philosophy because it is in the English language and has translated; to disprove this philosophy. It is not sufficient as was treated with Greek philosophy as treated in early Islam," says Maulana Muhammad Ali Mongari in fatwa No. 7.

3. "Religious education needs as well as the English language," says Maulana Shibli Nomani in Fatwa No. 9, "because without awareness of modern education, how can we contend with modern philosophy?" How can we preach Islam in Europe if we don't have a firm English language grasp? Without a working knowledge of English, how can we comprehend Aryan and Christian religious literature?"

Furthermore, their use of extreme terms such as non-Muslim language, paganism, liberalism, disputing, profanity, harmful, illicit, and language of destruction demonstrates their contempt for the English language. When we closely examine these words' use, it appears that they are enforcing certain conditions through these words.

4. There are numerous examples in thesefatwas where religious scholars have permitted English by using adversative conjunctions such as: until, because, if, after,then, so, and but, and so on. The use of theseconjunctions demonstrates religious scholars' prejudice against the English language.

5. Religious scholars have granted permission to learn and teach English on a conditional basis. "English, like all other languages, is a licit language," says Maulana Muhammad Ashraf Ali Thanvi in Fatwa No. 1. However, it is flawed due to three factors. In light of the following elements: 1. English is legal;

2. English is illegal, and 3. English is also a form of worship." "It is permissible if a person learns English so that he will be able to understand books, letters, and hidden meanings of words," says Shah Abdul Aziz Muhadis Dehelvi in Fatwa No. 2. "After completing Islamic education, if students join government institutions to acquire modern education, they should achieve their perfection," says Maulana Muhammad Qasim Nanotvi in fatwa No. 5. "It is right to learn English until nobody is culpable of calamity as it would be harmful to Islam," says Maulana Rasheed Ahmed Gangohi in fatwa No. 6. "If theologians know the English language, they would be able to convert over to Islamic jurisprudence in case of presents (hadia)," according to Maulana Shibli Nomani's fatwa No. 10. "Nowadays, it experienced that the spread of the English language is also causing evils," says Maulana Ashraf Ali Thanvi in fatwa No. 14. "So, it is better to be careful to some extent income should not be dependent on this subject, and there is no limit of greediness".

\section{DISCUSSION:}

In the past (pre-partition era), Muslim religious scholars opposed the learning and teaching of the English language. Some believed that anyone who learns or teaches English is a kafir (Non-believer). Because of this hostility against the foreign language, religious scholars never used a single English word in their lives. They also issued Fatawas against the English language, claiming that learning English is forbidden. The British government's indifference to Muslims was one of the main reasons for this attitude. The Muslim religious scholars believed that the Britishers forced Muslim students in their schools to study Christianity (Hassan, 2002). Muslim scholars were killed and imprisoned following the 1857 freedom war and deprived of their jobs, and made financially vulnerable just because they did not know English.

Some scholars advocated for English language learning and teaching because they realized that Muslims could not progress in the modern world unless they learned English. They preferred teaching and learning the English language to gain knowledge of modern subjects, compete with Christians, and stop propaganda against Muslims and their religion (Nadvi, 2006). Muslim religious scholars permitted learning English only if it did not affect the learners' religious and cultural identities and beliefs. They held the opinion that there should not be such education tothe English language that made them away from the teachings of Islam.

\section{CONCLUSION:}

The study was conducted to analyse the Muslim religious scholars' attitudes toward English language learning in Pakistan. A deep insight into the contents provided in the written fatawas discloses that the Mulslim religious scholars opposed the teaching and learning of English initially. After realizing that learning a language was indispensable if they wanted to keep pace with modern time, especially if they 
needed to protect their cultural, religious, and national identity in the global scenario. The English language and the other contemporary subjects that could meet this requirement of maintaining individuality as a nation should also be a part of education. The establishment of Aligarh Muslim College in India was the actualisation and realisation of the same philosophical grounds.

Realizing that English is one of the languages spoken and understood in that era, religious scholars had not only allowed to learn and use it, but they started learning it. Religious scholars started supporting English language teaching and learning, but this permission was conditional. The foremostrequirement was a strong commitment to Islamic values and beliefs' stability. Adversative conjunctions and conditional sentences, on the other hand, reveal Muslim religious scholars' prejudice against the English language.

\section{REFERENCES:}

1. $12^{\text {th }}$ Annual Report Madrassah Aalia Nazamia. (2001), Farangi Mahal, Lakhnao, (p144-145).

2. Abdulhai, A.M. (1964). Majmoa-e-Fatawa Molana Abdulhai, Translated by Molana Khursheed Alam. Muhammad Saeed and Sons, Karachi.

3. Alhasni, S.M. (1984). Seerat Maulana Muhammad Ali Mongeri. Majles-e-Nashriat-eIslam, Karachi.

4. Alhasni, S.M. (1984). Seerat Maulana Muhammad Ali Mongeri. Majles-e-Nashriat-eIslam, Karachi.

5. Ali, A.Y. (2003). Engrezi ehd mein Hindustan k Tamaddan ki Tehreek. Dost Assosiate Lahore.

6. Ali, S.A. (1993). Maulana Rehmat-Ullah Karanvi aur unki Tanseef" Izhar-ul-Haq". PunjabUniversity Lahore.

7. Dehlvi, S.M. (1960). Fatawa-e--. Deli Printing Press, Dehli.

8. Gangohi, M.R. (2004). Swaneh Qasmi. Maktaba Rahmania, Lahore.

9. Gillani, S.M.A. (1976). Sawaneh-e-Qasmi. Maktab-e-Rahmania, Lahore.

10. Hassan S.S. (2002). Naveed-e-Fiker. Maktba e Danial, Karachi.

11. Khan, S.A. (1990). Asarul Sanadeed. Martba Khaleeq Anjum, Urdu Academy dehli.

12. Mian, S.M.A. (1964). Ulema-e-Haq. Islami Kitab Ghar. Deo band.

13. Nadvi, S.S. (2006). Hayat-e-Shibli. Dar-ulMunisfeen, Azam Ghar.

14. Nasir-ud-Din, S. (1992). Aalim-e-Islam aur Aesaiat. Islamabad.
15. Naumani, S (1989). Khutbat-e-Shibli. National Book Foundation Lahore.

16. Nidvi, S. (1976). Hayat-e-Abdul Hae. Majles-eNashriat-e-Islam Karachi.

17. Nidvi, S.S. (2003). Yad-e-Raftgaan. Majles-eNashriat-e-Islam, Karachi.

18. Siddiqui, A.H. (1965). Maclnay ka Nazria-eTaleem. Roheel Khand Literary Society Karachi.

19. Thanesari, M.J. (1962). Tawareekh-e-Ajeeb Kala Pani. Suleman Academy Karachi.

20. Thanvi, M.A.A. (2007). Imdadul Fatawa' Martaba Molana Mufti Muhammad Shafi, Maktba Dar ul Aloom, Karachi.

Annexure:

\section{List of Fatawas Analysed}

Fatwa No. 1

Maulana Muhammad Ashraf Ali Thanvi was a wellknown Dar-ul-Uloom Deoband shura member (committee). He was one of the most respected religious scholars of Madrassah Deo-Band. He gave many fatwas in this regard in his book "Amdad-ulFatawa." This fatwa is taken from this book. "English is a licit language like other all languages. But three factors make it faulty; first of all, there are such subjects against the "Sharia," and people are unaware of sharia knowledge. Therefore, beliefs go against, and some thoughts are like profanity. Secondly, they should not adopt such subjects in which they have the company of Non-Muslims; their liberal impact affects the personality, sometimes in beliefs and sometimes in action. Third, if they don't adopt their company or it affects their character, they will have attention to make it a source of income whether the way of income is licit or illicit. These factors may reach the limit of profanity, whether this evil is apparent or hidden. If somebody is far from these factors, he does not lose; he believes that is a simple and authentic way. After getting a religious education, one who has its firm belief, is not bad in actions and has attention to getting licit income. And then he follows the action, for such person English is right and licit. And more than it, if he has attention to use it for people's service, it worships him. In a nutshell, sometimes English is illicit, sometimes it is licit, and sometimes it is worship (Thanvi, 2007).

\section{Fatwa No. 2}

Shah Abdul Aziz Muhadis Dehlvi was the first religious scholar and philosopher who gave fatwa about English. When the interviewer asked that "English is licit or not,"? Shah Abdul Aziz Muhadis Dehlvi said: "It is permitted if a person learns English so that he will be able to understand 
books, letters and hidden meanings of words. Zaid Bin Sabit (R.A) followed the order of the Holy Prophet (P.B.U.H) he learned the language of Jews and Christians (Yahood-o-Nasara) as well as learned the rules of the dictionary so that he would be able to reply to those letters which (Yahood-o-Nasara) sentto Holy Prophet (P.B.U.H). Still, if a person learns English to get luxurious enjoyment, it is illicit (Dehlvi, 1960).

\section{Fatwa No. 3}

Maulana Muhammad Jaffer Thanseri has written about the importance of the English language in his book "Twareekh-e-Ajeeb" that, "English is a language of Art and Sciences, one who does not know about English he is unaware about the knowledge of the world and without learning Englishhe will not be able to good in world affairs and partisan. There is no other language except English in the world with many sources of income" (Thanseri, 1962).

\section{Fatwa No. 4}

According to the autobiographer of Syed Nazir Hussain, who was named Maulana Fazal Hussain Behari, "When the English language was considered paganism, so Mian Sahib considered it as illicit to acquire knowledge of sensuality, and when it was prohibited to get a Government job, so Mian Sahib considered this earning licit" (Dehlvi, 1960).

Fatwa No. 5Maulana Muhammad Qasim Nanotvi, the founder of Madrassah Dar-ul-Uloom was well aware of the English language's need and importance. However, his opinion about English was that "After completing the Islamic education if students join Government institutions to acquire modern education they should accomplish their perfection" (Gillani, 1976).

\section{Fatwa No. 6}

Maulana Rasheed Ahmad Gangohi was a follower of Maulana Muhammad Qasim, and he said that it is licit to learn the English language. While answering a question, "whether the teaching and learning of English is right or not"? In reply, he said: "It is right to learn English until that nobody is culpable of calamity as well as it would be harmful to Islam" (Gangohi, 2004).

\section{Fatwa No. 7}

According to Maulana Muhammad Ali Mungari "It is compulsory to learn English to oppose modern philosophy because this philosophy is in English language and has been translated, to disprove this philosophy it is not sufficient as was treated with the Greek philosophy in an early Islam" (Alhasni, 1984).

\section{Fatwa No. 8}

Maulana Muhammad Ali Mungari said that "English is a language like Persian and Turkish languages, Persian and Turkish were the preliminary languages of non-followers their languages were published and introduced among Muslims when the speakers of their languages embarrassed Islam, thus if G.O.D.blesses as it is always hoped and when English (people) will embarrass Islam, English language will be more or less same as with the Turkish and Persian languages. As we see the books in Persian and Turkish INSHALLAH, we will see in English.

In a nutshell, by improving it, we can get them into English and Arabic also So that our coming generation can get the benefit and can keep theirminds and can save their religion. There should be such colleges where English and Arabic are taught ifa man sticks to English, he may acquire the necessaryknowledge in Arabic then get it translated in English" (Alhasni, 1984).

\section{Fatwa No. 9}

According to Maulana Shibli Nomani, "Religious education needs as well English language because without awareness of modern education, how can we contend modern philosophy? How we preach Islam in Europe without heightened awareness of English language? How can we understand the knowledge of Aryans and Christians' religious literature without the awareness of English"? (Naumani, 1989).

\section{Fatwa No. 10}

Maulana Shibli Nomani says about English language, "If the "theologians" know English language, they would be able to convert over Islamic jurisprudence in case of presents (Hadya), etc. the erroneous translation been Non-Muslims would not bedisputing in courts today" (Naumani, 1989).

\section{Fatwa No. 11}

Maulana Abdul Hai was one of the supporters who favoured Ali Garh College and gave fatwa in the support. In his opinion, "Learning of languagewhether the language of Non-Muslims is not prohibited from an Islamic point of view, this is in fact to acquire English language education is not prohibited according to Sharia.

Holy Prophet (P.B.U.H) himself ordered Zaid-binSabit to learn the language of Jews as is written in "Jamia Termzi", "to learn and read English is licit, 
until there is no harm to the religion and it is illicit to learn and read English and to learn its writing skills if it shows resemblance and affection with the English (people), there is no harm if we read these books and writings for the sake of information" (Abdulhai, 1964).

\section{Fatwa No. 12}

In the $12^{\text {th }}$ Annual Report of Madrassah Nazamia Aalia Maulana Abdul Bari talks about the importance of English language: "It is our great misfortune that Muslims are indulged in catastrophic disaster in case of Islamic education. There are two types of Muslims nowadays, one group of those who have got education from the old educational institutions; they people understand Islam on behalfof their old pattern and are not able to aware of the urgency of the modern era. Those who understand Islam without Islamic scholars but understand Islam with the help of European writers' literary composition and sagacious do not understand Islam from Muslim scholars. Still, they get awareness from Spencer and George Sale's Quranic translation. Historians have gone astray from the right way; it hurts me to see that modern educated people prefer the study of Islam with the help of translation written by George Sale instead of knowing the Arabic language" (12 $2^{\text {th }}$ Annual Report Madrassah Aalia Nazamia, 2001).

\section{Fatwa No. 13}

"English is under the kind patronage of the government of the day whereas the official supervision deprives the traditional knowledge of the Muslims. If they are not supported, the Muslims will not remain in touch with their past. The subjects under official control are being kept undergovernment, but Muslims' subjects are deprived or not under official patronage. But when the Muslims are deprived of their knowledge, they cannot remain Muslim, and the new government has drawn itself away from the patronage of a subject. These subjects have reached the least level of destruction under the new government's circumstances. The existence and survival of these subjects may be made possible only through the financial assistance of the Muslim community" (Khan, 1990).

\section{Fatwa No: 14}

"English is a language like all other languages, and English itself is not bad. It is one the blessing among all the blessings of Almighty ALLAH and Holy Prophet (P.B.U.H) himself talked into Persian, the language of idol worshipers. But because of some factors, it is a big evil. If we don't have those factors and purpose is only religious service like to deny Christianity and Jewish, or for the sake of licit income, it is licit. Zaid Bin Sabit (R.A) was ordered by of Holy Prophet (P.B.U.H) to learn the languageof Jews and Christians (Yahood-o-Nasara), to replyto those letters which (Yahood-o-Nasarah) sent to Holy Prophet (P.B.U.H) (Jamia Termzi). If we have those factors, then it is compulsory to avoid it... and

if a person is well aware of his religious beliefs, his attentions are good enough that he doesn't follow the customs and beliefs of non-Muslims and don't lose his faith. It is licit to learn English or Hindi for the sake of licit source of income. And people who don't have an awareness of their religion, especially whenit is very less and most probably such people have weak faith and are much allured towards non- Muslims, English is prohibited for such people, but nowadays it is mostly seen that with the spread of English is coming to the cause of evils, so it is better to be careful, and at some extent, the income is not dependent on this subject, and there is no limit of greediness" (Thanvi 2007). 